\title{
DESKRIPSI TINGKAT KEMAMPUAN BERPIKIR KREATIF (TKBK) PADA MATERI SEGIEMPAT SISWA KELAS VII SMP NEGERI 1 PABELAN KABUPATEN SEMARANG
}

\author{
Helarius Ryan Wahyu Santoso \\ versa1945@gmail.com \\ Alumni Program Studi Pendidikan Matematika \\ FKIP - Universitas Kristen Satya Wacana \\ Novisita Ratu \\ novisita.ratu@staff.uksw.edu \\ Program Studi Pendidikan Matematika \\ FKIP - Universitas Kristen Satya Wacana \\ Tri Nova Hasti Yunianta \\ trinova.yunianta@staff.uksw.edu \\ Program Studi Pendidikan Matematika \\ FKIP - Universitas Kristen Satya Wacana
}

\begin{abstract}
ABSTRAK
Jenis penelitian ini adalah penelitian deskriptif kualitatif yang bertujuan untuk mendeskripsikan tingkat kemampuan berpikir kreatif (TKBK) siswa kelas VII SMP Negeri 1 Pabelan Kabupaten Semarang. Subjek dalam penelitian ini adalah 5 siswa yang dipilih berdasarkan hasil tes kemampuan berpikir kreatif untuk mewakili masing-masing tingkat kemampuan berpikir kreatif. Teknik pengambilan sampel dilakukan dengan cara purposive. Penelitian dilakukan dengan cara tes dan wawancara. Berdasarkan hasil analisis data, dapat disimpulkan bahwa: (1) subjek yang termasuk dalam TKBK 4 (sangat kreatif), pada tingkat ini subjek mampu menunjukkan kefasihan, fleksibilitas dan kebaruan dalam menjawab soal; (2)subjek yang termasuk TKBK 3 (kreatif), pada tingkat ini subjekmampu menunjukkan kefasihan dan fleksibilitas; (3) subjek yang termasuk TKBK 2 (cukup kreatif), pada tingkat ini subjek mampu menunjukkan adanya fleksibilitas dalam menjawab soal; (4)subjek yang termasuk dalam TKBK 1 (kurang kreatif), pada tingkat ini subjek mampu menunjukkan adanya kefasihan; (5)subjek yang termasuk dalam TKBK 0 (tidak kreatif), pada tingkat ini subjek tidak menunjukkan adanya kefasihan, fleksibilitas dan kebaruan dalam menjawab soal.
\end{abstract}

Kata Kunci: tingkat kemampuan berpikir kreatif, segiempat 


\section{PENDAHULUAN}

Pembelajaran matematika di sekolah tidak hanya berkaitan dengan penguasaan materi matematika sebanyak-banyaknya, namun juga untuk mencapai tujuan-tujuan yang lebih tinggi misalnya mengembangkan kemampuan berpikir siswa (Mahmudi, 2010: 349). Berdasarkan Standar Isi dalam Permendiknas Nomor 22 Tahun 2006, mata pelajaran matematika diberikan untuk membekali peserta didik dengan kemampuan berpikir logis, analitis, sistematis, kritis, dan kreatif, serta kemampuan bekerjasama. Kemampuan tersebut diperlukan agar peserta didik dapat memperoleh, mengelola, dan memanfaatkan informasi untuk bertahan hidup pada keadaan yang berubah, tidak pasti, dan kompetitif. Kemampuan berpikir kreatif dalam matematika akan diperlukan dalam membantu mencapai kompetensi tersebut. Kemampuan berpikir kreatif berperan penting bagi kelangsungan kehidupan manusia. Kemampuan berpikir tersebut tidak hanya berguna dalam bidang matematika saja, namun sangat berguna dalam bidang lainnya. Bidang yang tidak memiliki hubungan dengan matematika sekalipun, kemampuan berpikir ini dapat diterapkan dan digunakan.

Menurut survei PISA (Programme for International Student Assesment) tahun 2009, Indonesia menempati peringkat ke61 dari 65 negara yang di survei dengan skor rata-rata kemampuan matematika siswa Indonesia yaitu 371, skor tersebut masih dibawah rata-rata internasional yaitu 496 (Litbang Kemendikbud, 2011). Survei dari TIMSS (Trends in Student Achievement in Mathematics and Science) pada tahun 2011 memperlihatkan Indonesia mengalami penurunan pada tahun sebelumnya yaitu
2007, dimana pada TIMSS tahun 2007 Indonesia berada pada peringkat 35 dari 49 negara peserta dengan nilai 397 dan pada TIMSS tahun 2011 Indonesia turun peringkat dan menghuni posisi 5 besar dari bawah yaitu peringkat 36 dari 40 negara peserta dengan nilai 386. Nilai yang diperoleh pada beberapa tahun tersebut memperlihatkan bahwa rata-rata skor prestasi matematika siswa SMP berada signifikan di bawah ratarata internasional. Berdasarkan survei tersebut, didapat fakta bahwa literasi matematika siswa juga rendah. Siswa hanya mampu memecahkan masalah sederhana, dan tidak bisa memecahkan masalahmasalah yang tidak rutin. Hal ini berarti bahwa kemampuan berpikir tingkat tinggi matematik siswa seperti berpikir kreatif masih kurang.

Kurangnya kemampuan berpikir kreatif juga ditunjukkan oleh beberapa penelitian terdahulu yang mengukur kemampuan berpikir kreatif yang mendukung dengan penelitian ini, seperti halnya penelitian yang dilakukan oleh Putri (2013) menyimpulkan bahwa pada SMP yang dituju terdapat 3 subjek yang termasuk dalam TKBK 0 (tidak kreatif), terdapat 2 subjek yang termasuk dalam TKBK 1 (kurang kreatif), terdapat 6 subjek yang termasuk dalam TKBK 2 (cukup kreatif), terdapat 3 subjek yang termasuk dalam TKBK 3 (kreatif), dan terdapat 16 subjek yang termasuk dalam TKBK 4 (sangat kreatif). Penelitian relevan lainnya seperti yang dilakukan oleh Fardah (2013) yang bertujuan untuk menganalisis proses berpikir kreatif dan kemampuan siswa melalui tugas open-ended, menyimpulkan bahwa pola berpikir kreatif siswa tinggi sebanyak 20\% dari jumlah siswa, sedang sebanyak 33,33\%, dan rendah sebanyak $46,67 \%$. Beberapa penelitian tersebut 
menunjukkan masih banyak siswa yang termasuk dalam kemampuan berpikir kreatif yang rendah sehingga pengembangan hendaknya perlu dilakukan.

Mengembangkan kemampuan berpikir logis, analitis, sistematis, kritis maupun bekerjasama sudah lama menjadi fokus dan perhatian pendidikan matematika di sekolah, karena hal itu berkaitan dengan sifat dan karakteristik keilmuan matematika (Siswono, 2009), tetapi fokus dan perhatian pada upaya peningkatan kemampuan berpikir kreatif dalam pembelajaran matematika masih jarang dikembangkan. Kemampuan ini (berpikir kreatif) dalam konteks pembelajaran matematika, adalah kemampuan yang merangsang siswa untuk menemukan solusi yang beragam dari kemampuan berpikir siswa. Siswa dituntut untuk tidak lagi terbatas pada pemikiran yang konvergen melainkan pemikiran yang divergen. Berpikir kreatif mulai mendapat perhatian oleh peneliti pada tahun 1950an. Beberapa istilah berpikir kreatif yang digunakan oleh para ahli antara lain berpikir divergen sebagai lawan dari berpikir konvergen. Sampai saat ini sudah banyak beberapa ahli yang mengungkapkan pendapatnya tentang kemampuan berpikir kreatif. Martin (Mahmudi, 2010: 2) sebagai salah satu ahli menyebutkan bahwa kemampuan berpikir kreatif adalah kemampuan untuk menghasilkan ide atau cara baru dalam menghasilkan suatu produk. Sejalan dengan Martin (Siswono, 2007: 3) mengartikan kemampuan berpikir kreatif sebagai suatu kemampaun yang digunakan seseorang dalam mensintesis (menjalin) ideide, membangun ide-ide baru dan menerapkannya untuk menghasilkan produk yang baru secara fasih (fluency) dan fleksibel. Kemampuan berpikir kreatif dapat diukur dengan beberapa kriteria. Silver (1997) menjelaskan bahwa untuk menilai kemampuan berpikir kreatif anak-anak dan orang dewasa dapat dilakukan dengan menggunakan "The Torrance Test of Creative Thinking (TTCT)". Tiga komponen kunci yang dinilai dalam berpikir kreatif menggunakan TTCT adalah kefasihan (fluency), fleksibilitas (flexiblity) dan kebaruan (novelty). Siswono mengadaptasi alat ukur tes dari Silver tersebut dengan menggunakan tiga komponen kunci yang sama. Kefasihan (fluency) mengacu pada kemampuan siswa dalam memberikan bermacam-macam jawaban, fleksibilitas (flexiblity) mengacu pada kemampuan siswa dalam menyelesaikan masalah tidak hanya dengan satu cara tetapi bisa memberikan cara lain, dan kebaruan (novelty) mengacu pada kemampuan siswa mengajukan suatu masalah yang berbeda dari masalah yang diajukan sebelumnya.

Siswono (2006) dalam jurnalnya juga mengungkapkan bahwa terdapat 5 tingkatan dari kemampuan berpikir kreatif. Dimulai dari tingkat 4 yang tertinggi sampai tingkat 0 sebagai yang terendah. Setiap tingkat kemampuan berpikir kreatif ini memiliki beberapa karakteristik seperti yang terlihat pada Tabel 1 .

Terdapat dua faktor yang dapat mempengaruhi kemampuan berpikir kreatif yaitu faktor dorongan dari dalam diri individu (internal) dan faktor dorongan dari lingkungan atau luar diri individu (eksternal). Munandar (2012) menjelaskan bahwa motivasi instriksik setiap orang untuk mewujudkan potensinya selalu ada, motivasi tersebut hendaknya dibangun sejak dini. Hal ini dapat dilakukan dengan memperkenalkan individu dengan kegiatan-kegiatan kreatif, dengan tujuan untuk memunculkan rasa ingin tahu, dan untuk melakukan hal-hal baru. Sedangkan motivasi ekstrinsik indi- 
Tabel 1 Kriteria Tingkat Kemampuan Berpikir Kreatif (TKBK)

\begin{tabular}{|c|c|}
\hline TKBK & Kriteria \\
\hline $\begin{array}{l}\text { TKBK } 4 \\
\text { (Sangat } \\
\text { Kreatif) }\end{array}$ & $\begin{array}{l}\text { Siswa mampu menyelesaikan suatu masalah dengan lebih dari satu alternatif jawaba } \\
\text { maupun cara penyelesaian atau membuat masalah yang berbeda-beda dengan lanca } \\
\text { (fasih) dan fleksibel. Siswa yang mencapai tingkat ini dapat dinamakan sebagai sisw } \\
\text { sangat kreatif. }\end{array}$ \\
\hline $\begin{array}{l}\text { TKBK } 3 \\
\text { (Kreatif) }\end{array}$ & $\begin{array}{l}\text { Siswa mampu menunjukkan suatu jawaban yang bau dengan cara penyelesaian yan } \\
\text { berbeda (fleksibel) meskipun tidak fasih atau membuat berbagai jawaban yang bar } \\
\text { meskipun tidak dengan cara yang berbeda (tidak fleksibel). Selain itu, siswa dap } \varepsilon \\
\text { membuat masalah yang berbeda dengan lancar (fasih) meskipun jawaban masalah tungg } \\
\text { atau membuat masalah yang baru dengan jawaban divergen. Siswa yang mencapai tingk } \\
\text { ini dapat dinamakan sebagai siswa kreatif. }\end{array}$ \\
\hline $\begin{array}{l}\text { TKBK } 2 \\
\text { (Cukup } \\
\text { Kreatif) }\end{array}$ & $\begin{array}{l}\text { Siswa mampu membuat satu jawaban atau masalah yang berbeda dari kebiasaan umur } \\
\text { meskipun tidak dengan fleksibel atau fasih, atau mampu menunjukkan berbagai car } \\
\text { penyelsaian yang berbeda dengan fasih meskipun jawaban yang dihasilkan tidak bart } \\
\text { Siswa yang mencapai tingkat ini dapat dinamakan sebagai siswa cukup kreatif. }\end{array}$ \\
\hline $\begin{array}{l}\text { TKBK } 1 \\
\text { (Kurang } \\
\text { Kreatif) }\end{array}$ & $\begin{array}{l}\text { Siswa tidak mampu membuat satu jawaban atau membuat masalah yang berbeda (baru, } \\
\text { meskipun salah satu kondisi berikut dipenuhi, yaitu cara penyelesaian yang dibuc } \\
\text { berbeda-beda (fleksibel) atau jawaban/masalah yang dibuat beragam (fasih). Siswa yan } \\
\text { mencapai tingkat ini dapat dinamakan sebagai siswa kurang kreatif. }\end{array}$ \\
\hline $\begin{array}{l}\text { TKBK } 0 \\
\text { (Tidak } \\
\text { Kreatif) }\end{array}$ & $\begin{array}{l}\text { Siswa tidak mampu membuat alternatif jawaban maupun cara penyelesaian atau membuc } \\
\text { masalah yang berbeda dengan lancar (fasih) dan fleksibel. Siswa yang mencapai tingkc } \\
\text { ini dapat dinamakan sebagai siswa tidak kreatif. }\end{array}$ \\
\hline
\end{tabular}

vidu yang berasal dari lingkungan mampu mendorong munculnya kreativitas, hendaknya lingkungan sekitar dapat menjadi pendorong bagi invidu untuk mampu mengembangkan kreativitasnya. Penciptaan kondisi keamanan dan kebebasan psikologis memungkinkan timbulnya kemampuan berpikir kreatif.

Kemampuan berpikir kreatif siswa dapat diidentifikasi dengan pemberian soal terbuka. Foong (2002) menyebutkan bahwa soal terbuka adalah salah satu cara penyajian berbagai macam pendekatanyang mungkin untuk menyelesaikan soal atau adanya berbagai macam kemungkinan jawaban. Soal terbuka merupakan soal yang dapat digunakan untuk mengukur tingkat kemampuan berpikir kreatif siswa. Siswa diberikan soal terbuka tujuan utamanya bukan untuk mendapat jawaban yang benar tetapi untuk mengetahui tingkat kemampuan berpikir kreatifnya. Soal terbuka adalah soal yang memiliki lebih dari satu jawaban atau cara penyelesaian yang benar.

Soal terbuka akan diterapkan dalam pembelajaran matematika. Ruang lingkup pelajaran matematika yang diajarkan di SMP meliputi aspek-aspek bilangan, geometri dan pengukuran, aljabar, peluang dan statistika. Salah satu cabang kajian dalam metematika adalah materi segiempat yang masuk dalam ilmu geometri. Materi segi empat dapat digunakan dalam mengidentifikasi kemampuan berpikir kreatif siswa (Siswono, 2007). Materi segiempat pada SMP kelas VII membahas tentang macammacam segiempat yaitu ada trapesium, 
jajargenjang, persegi panjang, persegi, belah ketupat dan layang-layang. Dimana bangunbangun segiempat tersebut dibahas baik secara pengertian, sifat-sifat, luas dan kelilingnya. Materi segiempat sangat mendukung untuk digunakan dalam mengukur tingkat kemampuan berpikir kreatif siswa.

Berdasarkan uraian di atas, peneliti ingin mendeskripsikan tingkat kemampuan berpikir kreatif (TKBK) pada materi segiempat siswa kelas VII SMP Negeri 1 Pabelan Kabupaten Semarang. Penelitian ini diharapkan dapat memberikan deskripsi tentang tingkat kemampuan berpikir kreatif sehingga dapat membantu guru maupun sekolah dalam memperbaiki dan merencanakan pembelajaran agar lebih memperhatikan tingkat kemampuan berpikir kreatif masing-masing siswa.

\section{METODE PENELITIAN}

Jenis penelitian ini adalah deskripsi kualitatif yaitu penelitian yang menggunakan data kualitatif dan dideskripsikan untuk menghasilkan gambaran yang jelas dan terperinci mengenai tingkat kemampuan berpikir kreatif siswa pada materi segiempat. Penentuan subjek penelitian menggunakan teknik purposive sampling yaitu teknik pengambilan sampel dengan pertimbangan tertentu (Sugiyono, 2012: 300). Subjek penelitian ini adalah 5 siswa kelas VII B yang dipilih berdasarkan hasil tes kemampuan berpikir kreatif, dimana 5 siswa itu mewakili masing-masing tingkat kemampuan berpikir kreatif. Kelima subjek tersebut yaitu: (a) siswa DAS yang mewakili kategori sangat kreatif (TKBK 4), subjek mampu berkomunikasi dengan baik, memiliki respon yang cukup baik, mudah dalam menangkap suatu pertanyaan atau instruksi, dan mampu memberikan alasan jawaban dengan baik meskipun awalnya terlihat malu-malu; (b) siswa RW yang mewakili kategori kreatif (TKBK 3), subjek mampu berkomunikasi dengan cukup baik, memberikan jawaban pertanyaan dengan singkat dan sedikit sulit dalam memperluas jawabannya, namun mudah menangkap suatu pertanyaan atau instruksi dan berani menyatakan kesulitannya; (c) siswa DFA yang mewakili kategori cukup kreatif (TKBK 2), subjek mampu berkomunikasi dengan baik dan tidak malumalu, mampu memberikan jawaban dengan cukup baik, mudah dalam menangkap instruksi dan pertanyaan; (d) siswa LNM yang mewakili kategori kurang kreatif (TKBK 1), subjek mampu memberikan alasan jawaban dengan baik, mampu berkomunikasi baik secara verbal, mudah mengerti suatu pertanyaan atau instruksi.; dan (e) siswa RNW yang mewakili kategori tidak kreatif (TKBK 0), subjek terlihat pendiam namun mampu dengan tegas memberikan alasan dari jawabannya, mudah dalam menangkap suatu pertanyaan maupun instruksi namun kurang mampu berkomunikasi dengan lancar.

Penelitian ini menggunakan teknik triangulasi dalam pengumpulan data, yaitu dengan tes kemampuan berpikir kreatif, wawancara semi terstruktur, dan dokumentasi. Instrumen yang digunakan dalam penelitian ini adalah tes kemampuan berpikir kreatif (tipe soal open-ended) dan pedoman wawancara. Instrumen tes yang digunakan dibuat dengan mengacu pada indikator kemampuan berpikir kreatif dari Siswono seperti pada Tabel 2.

Penelitian ini menggunakan teknik analisis data Miles dan Huberman yaitu reduksi data, penyajian data dan penarikan kesimpulan (Sugiyono, 2012: 338). Analisis data dilakukan dengan menganalisis data 
Tabel 2 Deskripsi Indikator KemampuanBerpikir Kreatif dari Siswono

\begin{tabular}{ll}
\hline \multicolumn{1}{c}{ Indikator } & \multicolumn{1}{c}{ Kriteria Kemampuan } \\
\hline Kefasihan & $\begin{array}{l}\text { Mampu menyelesaikan masalah dengan bermacam-macam } \\
\text { interpretasi, metode penyelesaian atau jawaban masalah }\end{array}$ \\
\hline Fleksibilitas & $\begin{array}{l}\text { Mampu memecahkan masalah dalam satu cara, kemudian } \\
\text { menggunakan cara lain. } \\
\end{array}$ \\
& Mampu mendiskusikan berbagai metode penyelesaian \\
\hline Kebaruan & $\begin{array}{l}\text { Mampu memeriksa beberapa metode penyelesaian atau } \\
\text { jawaban, kemudian membuat lainnya yang berbeda. }\end{array}$ \\
\hline
\end{tabular}

hasil tes dan analisis data hasil wawancara. Analisis data hasil tes dilakukan dengan memperhatikan indikator kefasihan, fleksibilitas, dan kebaruan. Analisis dilakukan pada jawaban dan langkah-langkah penyelesaian yang digunakan subjek. Setelah menganalisis hasil tes dilakukan wawancara terhadap 5 subjek terpilih yang mewakili masing-masing tingkat. Keabsahan data dalam penelitian ini dijamin dengan menggunakan triagulasi metode. Teknik ini dilakukan dengan cara membandingkan hasil wawancara dengan hasil tes yang dikerjakan. Wawancara dilakukan dengan pertanyaan yang sama tetapi dengan instruksi yang lebih mendetail bagi subjek untuk menjawab. Wawancara dilakukan tujuannya untuk mengetahui alasan subjek dalam memberikan jawaban soal tes. Hasil wawancara berupa data kualitatif yang sudah diperiksa keabsahannya kemudian dianilisis dengan langkah-langkah sesuai dengan teknik analisis Miles dan Huberman. Pertama, mereduksi data yaitu dalam hal ini yang dimaksud adalah kegiatan yang mengacu pada proses menajamkan, menggolongkan informasi, dan membuang data mentah yang diperoleh dari lapangan tentang tingkat kemampuan berpikir kreatif siswa dalam menyelesaikan soal yang diberikan kepada subyek. Kedua, penyajian data yaitu meli- puti kegiatan mengklasifikasi dan mengidentifikasi data untuk menarik kesimpulan. Penyajian data yang dilakukan dalam penelitian ini adalah pengklasifikasian dan mendeskripsikan berdasarkan tiga kriteria utama berpikir kreatif yaitu kefasihan, fleksibilitas dan kebaruan, siswa dikategorikan pada tingkat kemampuan berpikir kreatif yang terdiri dari lima tingkat, yaitu sangat kreatif, kreatif, cukup kreatif, kurang kreatif, dan tidak kreatif. Terakhir menarik kesimpulan atau verfikasi untuk mendeskripsikan tingkat kemampuan berpikir kreatif pada setiap kelompok berdasarkan penyajian data.

\section{HASIL DAN PEMBAHASAN}

Terdapat tiga indikator kemampuan berpikir kreatif menurut Siswono yaitu kefasihan, fleksibilitas, dan kebaruan. Siswono juga mengungkapkan bahwa terdapat 5 tingkat kemampuan berpikir kreatif (TKBK) yaitu TKBK 4 (sangat kreatif), TKBK 3 (kreatif), TKBK 2 (cukup kreatif), TKBK 1 (kurang kreatif) dan TKBK 0 (tidak kreatif). Berdasarkan hasil penelitian menunjukkan bahwa terdapat perbedaan deskripsi dari masing-masing tingkat kemampuan berpikir kreatif pada materi segiempat. Subjek pada tingkat tinggi mampu memperlihatkan beberapa indikator 
berpikir kreatif sekaligus sedangkan pada tingkat yang lebih rendah subjek belum mampu memperlihatkan indikator kemampuan berpikir kreatif yang ada.

\section{Subjek DAS memiliki Tingkat Kemampuan Berpikir Kreatif 4}

Subjek yang termasuk dalam TKBK 4 (sangat kreatif), menunjukkan bahwa subjek mampu memunculkan ketiga indikator kemampuan berpikir kreatif dalam menjawab soal yang diberikan. Seperti yang terlihat pada Gambar 1, Subjek DAS mampu memberikan 5 segiempat yang berbeda dan 1 bangun gabungan lengkap beserta ukurannya, dimana bangun-bangun tersebut memiliki luas yang sama besar dengan bangun persegi panjang yang diketahui. Hal tersebut menunjukkan bahwa kefasihan mampu diperlihatkan oleh subjek DAS, dimana subjek tidak hanya memberikan satu atau dua bangun saja tetapi dengan fasih subjek DAS mampu memberikan beberapa bangun yang dia buat dengan luas yang sama seperti yang ditanyakan dalam soal.

Subjek DAS juga mampu memberikan jawaban yang berbeda untuk mencari suatu luas bangun yang telah dia buat sebelumnya, seperti yang terlihat pada Gambar 2. subjek DAS mampu mencari luas dari layang-layang yang dia buat bukan dengan rumus luas pada umumnya melainkan subjek DAS mampu menemukan luas dari layang-layang tersebut dari luas segitiga yang dia dapat setelah membagi layanglayang tersebut, yang kemudian luas kedua segitiga tersebut dijumlahkan untuk menemukan luas layang-layang. Hal tersebut menunjukkan subjek DAS mampu memperlihatkan fleksibilitas dalam dirinya, dimana subjek DAS mampu memberikan alternatif jawaban lain yaitu mampu menemukan luas layang-layang bukan dengan rumus luas yang telah diketahui tetapi subjek DAS menemukan luas layang-layang tersebut dari jumlah luas segitiga yang telah dia dapat sebelumnya

Subjek DAS juga mampu memberikan sesuatu yang baru dari jawabannya seperti yang terlihat pada Gambar 3, subjek DAS mampu membuat tipe soal yang tidak biasa dibuat oleh subjek lainnya, dimana subjek membuat soal cerita. Subjek juga mampu menyelesaikan soal yang dia buat tersebut secara tepat. Berdasarkan hal tersebut menunjukkan bahwa indikator kebaruan mampu diperlihatkan oleh subjek DAS dengan mampu memberikan jawaban yang baru dan berbeda dari pada umumnya.

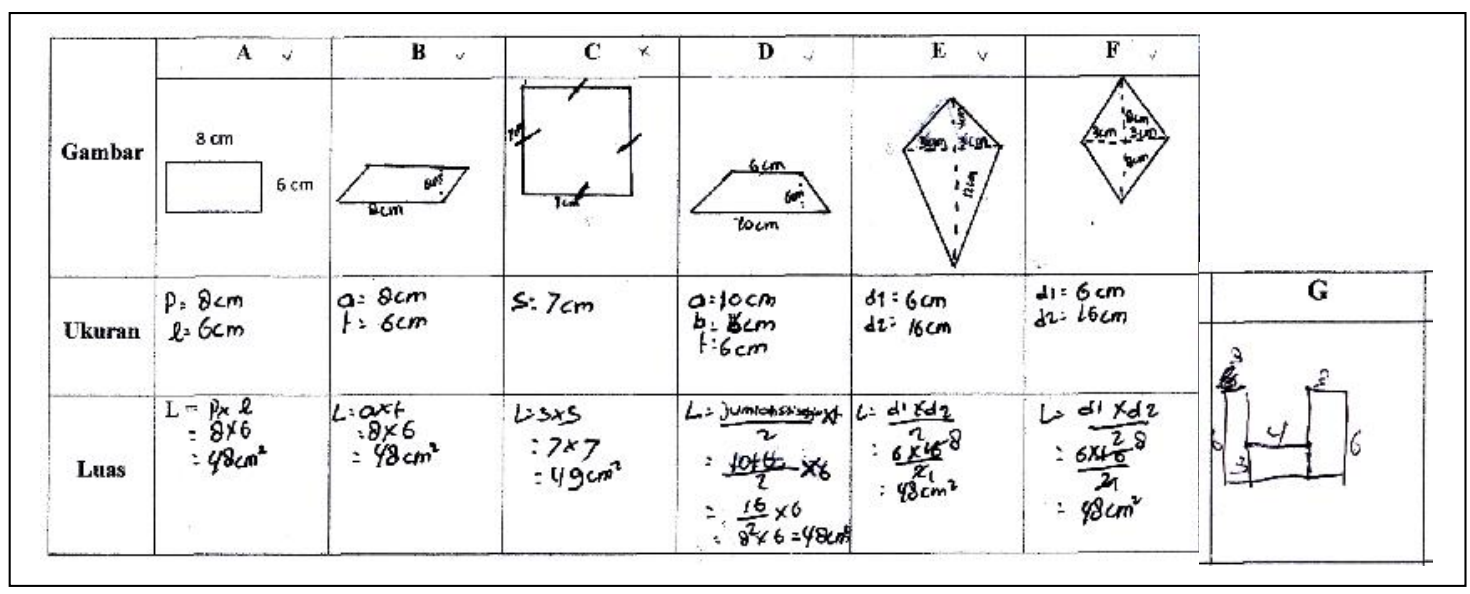

Gambar 1 Jawaban tertulis soal nomor 1 subjek DAS 


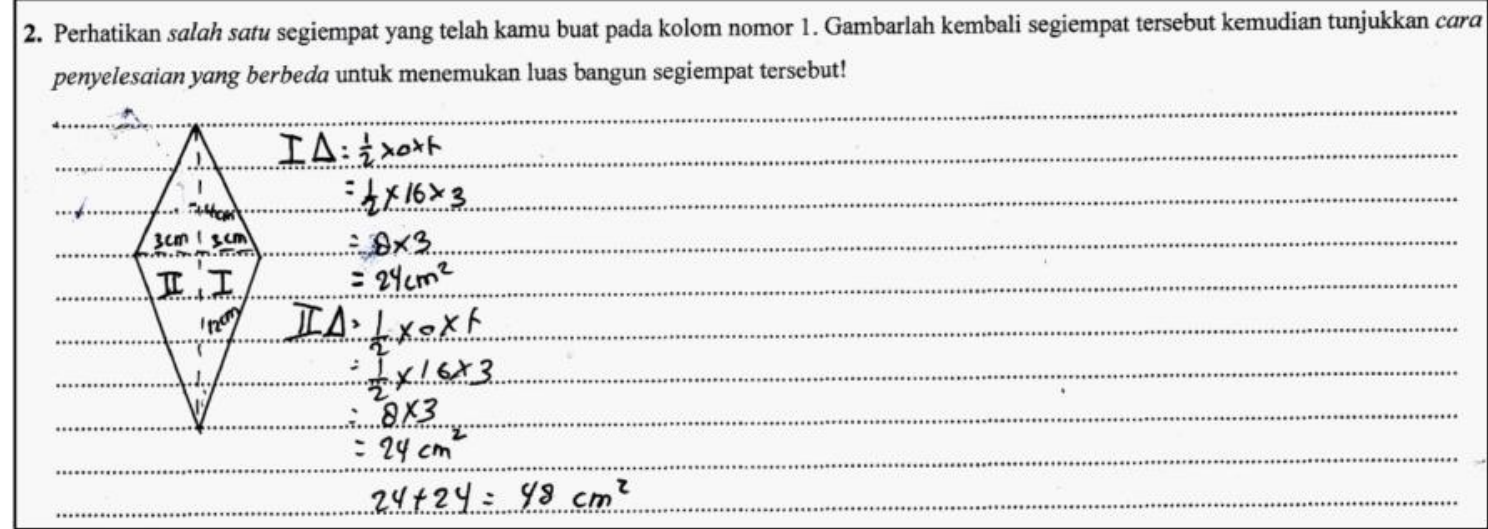

Gambar 2 Jawaban tertulis soal nomor 2 subjek DAS

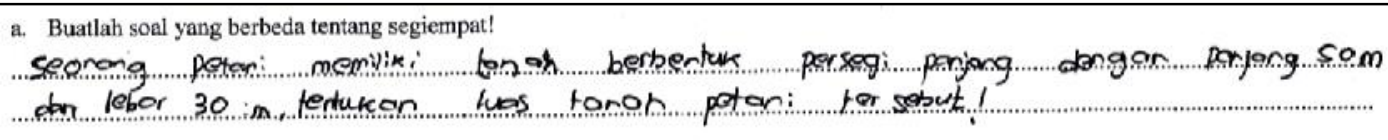

Gambar 3 Jawaban tertulis soal nomor 3 subjek DAS

\section{Subjek RW memiliki Tingkat Kemampuan Berpikir Kreatif 3}

Subjek yang termasuk dalam TKBK 3 (kreatif), menunjukkan bahwa subjek mampu memperlihatkan dua indikator kemampuan berpikir kreatif yaitu kefasihan dan fleksibilitas. Sebagaimana yang terlihat pada Gambar 4, Subjek RW mampu memberikan jawaban yang lengkap dimana subjek memberikan 7 segiempat dengan berbagai ukuran yang berbeda meskipun ada yang beberapa bangun yang sama dan belum tepat. Beberapa segiempat tersebut memiliki luas yang sama dengan bangun persegi panjang yang diketahui walaupun ada satu bangun yang kurang tepat. Terlepas dari satu jawaban yang kurang tepat tersebut, subjek RW sudah mampu menunjukkan kefasihan, dimana subjek mampu mengisi semua kolom yang tersedia dengan beberapa bangun segiempat yang berbeda dan memiliki luas yang sama.

\begin{tabular}{|c|c|c|c|c|c|c|c|}
\hline A & B & 5 & D $\checkmark$ & E & F & G & H \\
\hline $8 \mathrm{~cm}$ & $\stackrel{\theta \mathrm{Cm}}{\pi}$ & & & & & & \\
\hline $\begin{array}{l}P=8 \mathrm{~cm} \\
Q=6 \mathrm{~cm}\end{array}$ & $\begin{aligned} B-a & =8 \mathrm{~cm} \\
t & =6 \mathrm{~cm}\end{aligned}$ & $\begin{array}{l}\text { Jminghosi spjegar } \\
=12 \mathrm{~cm}+4 \mathrm{~cm} \\
=16 \mathrm{~cm} \\
=1.6 \mathrm{~cm}\end{array}$ & $\begin{array}{l}d_{1}=12 \mathrm{~cm} \\
d_{2}=8 \mathrm{cn}\end{array}$ & $\begin{array}{l}\text { Julh gुs }=5+7 \\
t=8 \mathrm{~cm}\end{array}$ & $\begin{array}{l}d_{1}=10 \mathrm{~cm} \\
d 2=10 \mathrm{cos}\end{array}$ & $\begin{array}{l}l=8 \mathrm{~cm} \\
l=6 \mathrm{~cm}\end{array}$ & $\begin{array}{l}a=6 \mathrm{~cm} \\
t=3 \mathrm{cn}\end{array}$ \\
\hline $\begin{aligned} \mathrm{L} & =p \times l \\
& =8 \mathrm{cos} \times 6 \mathrm{~cm} \\
& =48 \mathrm{~cm}^{2}\end{aligned}$ & $\begin{aligned} L & =a x t \\
& =8 \operatorname{con} \times 6 \mathrm{~cm} \\
& =48 \mathrm{~cm}^{2}\end{aligned}$ & 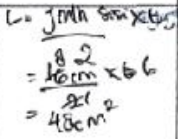 & $\begin{aligned} L & =\frac{d_{1} x d^{2}}{c^{2}} \\
& =\frac{x_{2}^{2} \mathrm{em}^{2} \mathrm{dem}}{2 !} \\
& =48 \mathrm{~cm}^{2}\end{aligned}$ & $\begin{aligned} L & =\frac{\operatorname{senh} \sin \times t}{6^{2}} \\
& =\frac{b^{2} \times \mathrm{cm}}{2-1} \\
& =48 \mathrm{~cm}^{2}\end{aligned}$ & 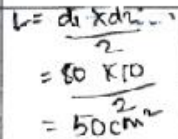 & $\begin{aligned} L & =p \times l \\
& =A \times 6 \\
& =A 8 \mathrm{~cm}^{2}\end{aligned}$ & $\begin{aligned} L & =a \times t \\
& =6 \times 8 \\
& =40 \mathrm{~cm}^{2}\end{aligned}$ \\
\hline
\end{tabular}

Gambar 4 Jawaban tertulis soal nomor 1 subjek RW 
Subjek RW juga mampu menunjukkan adanya fleksibilitas dalam dirinya, seperti yang terlihat pada Gambar 5. subjek RW mampu menunjukkan bahwa subjek tidak hanya mampu memberikan satu cara dalam menemukan luas persegi panjang, namun subjek mampu menemukan cara lain yaitu dengan membagi persegi panjang yang diketahui menjadi dua segitiga siku-siku yang selanjutnya dua segitiga tersebut dihitung luasnya dan dijumlahkan sehingga menemukan luas persegi panjang yang diketahui. Indikator fleksibilitas jelas mampu dimunculkan subjek RW karena subjek mampu memberikan alternatif lain dalam mencari suatu luas segiempat tidak menggunakan rumus yang telah ada.

Hanya saja subjek RW belum mampu memberikan sesuatu yang berbeda atau baru, subjek memberikan jawaban yang terbilang masih umum dan belum baru seperti yang terlihat pada Gambar 6. Subjek RW masih membuat soal yang umum seperti hanya mencari keliling dari persegi panjang saja, hal tersebut menunjukkan bahwa indi- kator kebaruan belum mampu ditunjukkan oleh subjek RW.

\section{Subjek DFA memiliki Tingkat Kemampuan Berpikir Kreatif2}

Subjek yang termasuk dalam TKBK 2 (cukup kreatif), menunjukkan bahwa subjek mampu memperlihatkan satu indikator kemampuan berpikir kreatif yaitu fleksibilitas. Subjek DFA mampu memberikan alternatif jawaban dengan baik, seperti yang terlihat pada Gambar 7, dimana sama halnya dengan subjek RW, subjek DFA mampu menggunakan cara lain untuk menemukan luas persegi panjang yang diketahui. Subjek menunjukkan cara lain untuk menentukan luas persegi panjang, bukan dengan rumus biasa yaitu panjang dikali lebar tetapi dengan membagi persegi panjang menjadi dua buah segitiga siku-siku, dimana selanjutnya kedua buah segitiga tersebut dihitung luasnya dan kemudian dijumlahkan sehingga mendapatkan luas dari persegi panjang. Hal tersebut menunjukkan bahwa subjek DFA memiliki fleksibilitas dalam dirinya.

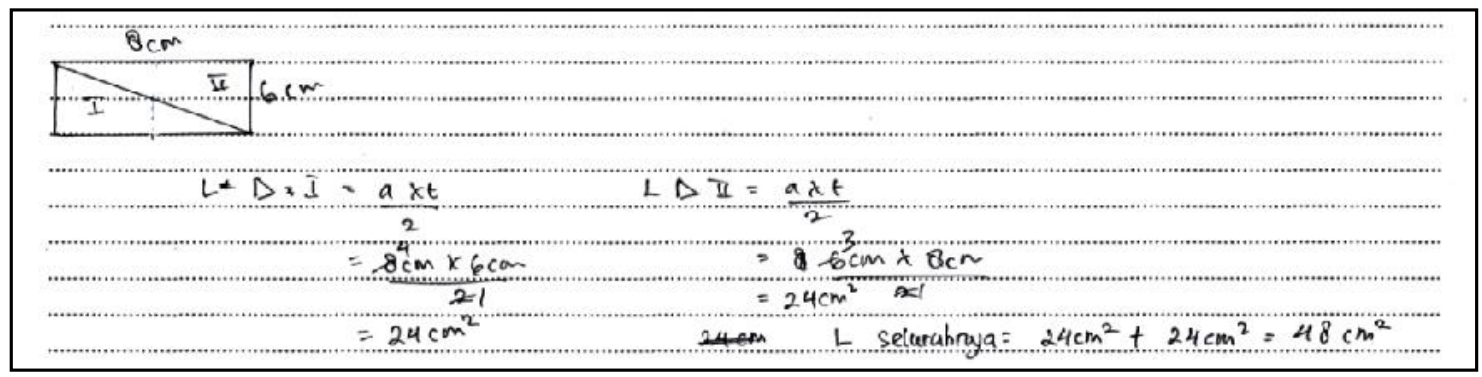

Gambar 5 Jawaban tertulis soal nomor 2 subjek RW

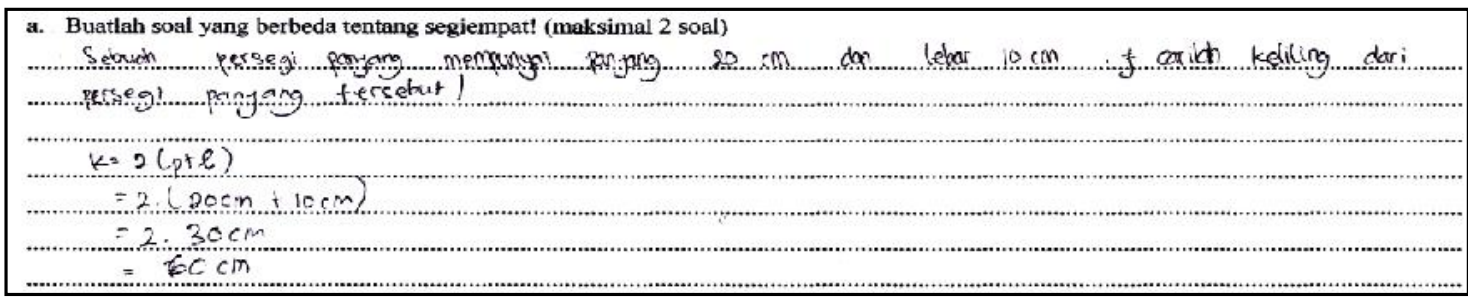

Gambar 6 Jawaban tertulis soal nomor 3 subjek RW 


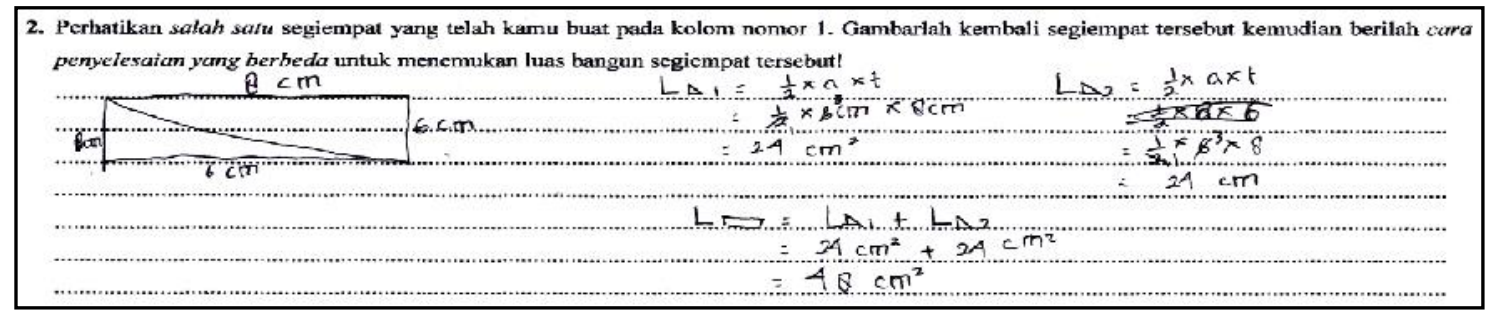

Gambar 7 Jawaban tertulis soal nomor 2 subjek DFA

Fleksibilitas yang dimiliki subjek DFA tidak didukung oleh kefasihan dan kebaruan dalam menyelesaikan soal. Sebagaimana terlihat pada Gambar 8, subjek DFA mampu memberikan 5 segiempat dan 1 bangun gabungan tetapi beberapa jawaban yang diberikan masih belum tepat. Bangun gabungan yang dibuat juga belum lengkap karena belum terdapat ukuran-ukurannya. Hal tersebut menunjukkan bahwa subjek DFA belum mampu memberikan bermacam-macam jawaban sehingga indikator kefasihan belum mampu dimunculkan.

Subjek DFA juga belum mampu menunjukkan adanya kebaruan dalam dirinya, ini dapat dilihat dari jawaban subjek seperti pada Gambar 9. Subjek DFA hanya membuat soal yang hampir sama dengan soal sebelumnya bahkan subjek hanya mengganti lebar yang diketahui saja. Subjek DFA tidak mampu membuat jawaban yang berbeda dari tingkat lainnya sehingga menunjukkan bahwa indikator kebaruan belum mampu dimunculkan subjek pada tingkat ini.

\section{Subjek LNM memiliki Tingkat Kemampuan Berpikir Kreatif1}

Subjek yang termasuk dalam TKBK 1 (kurang kreatif), menunjukkan bahwa subjek mampu memperlihatkan satu indikator kemampuan berpikir kreatif yaitu kefasihan. Berbeda dengan TKBK 2 subjek pada tingkat ini hanya mampu memperlihatkan kefasihan dalam menjawab, ini dapat dilihat pada Gambar 10. Subjek LNM mampu memberikan 5 segiempat yang berbeda lengkap dengan ukuran dan luas yang sesuai dengan yang ditanyakan. Subjek LNM mampu memberikan variasi jawaban yaitu dengan berbagai macam segiempat yang subjek buat, hal tersebut menunjukkan subjek LNM sudah memiliki kefasihan dalam dirinya.

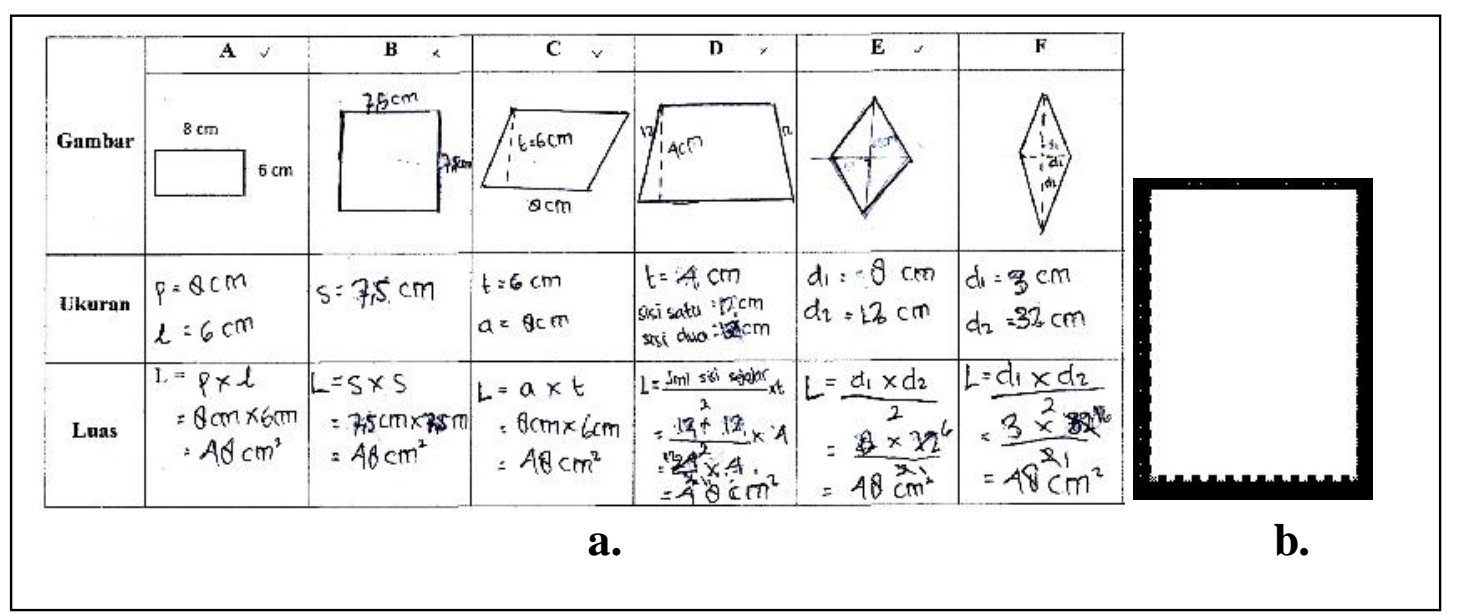

Gambar 8 Jawaban tertulis soal nomor 1 subjek DFA 


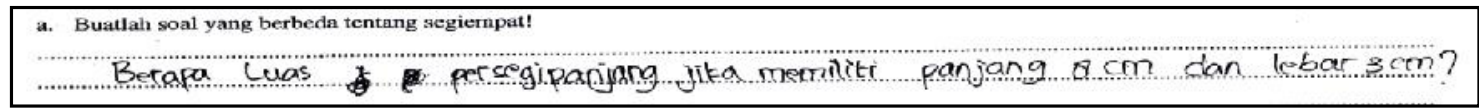

Gambar 9 Jawaban tertulis soal nomor 3 subjek DFA

\begin{tabular}{|c|c|c|c|c|c|c|}
\hline & A & B & C & $\checkmark$ & E & $\mathbf{F}$ \\
\hline Gambar & $8 \mathrm{~cm}$ & lbur & $\mathrm{Bem}$ & $10 \mathrm{~cm}$ & & \\
\hline Ukuran & $\begin{array}{l}P=8 \mathrm{~cm} \\
L=6 \mathrm{~cm}\end{array}$ & $\begin{aligned} a & =16 \mathrm{~cm}+\mathrm{cm} \\
& =29 \\
t & =4 . \mathrm{cm}\end{aligned}$ & $\begin{array}{l}a=8 \mathrm{um} \\
t=6 \mathrm{~cm}\end{array}$ & $\begin{aligned} a & =100 \mathrm{~m}+16 \mathrm{~cm} \\
& =24 \mathrm{~cm} \\
t & =1 \mathrm{~km}\end{aligned}$ & $\begin{array}{l}d_{1}=16 \mathrm{~cm} \\
d_{2}=3 \mathrm{~cm}\end{array}$ & $\begin{array}{l}d t=12 \mathrm{~cm} \\
d z=8 \mathrm{~cm}\end{array}$ \\
\hline Luas & $\begin{aligned} \mathbf{L} & =p \times L \\
& =8 \mathrm{sun} \times \mathrm{sum} \\
& =48 \mathrm{~cm}^{2}\end{aligned}$ & $\begin{aligned} L & =\frac{5+5}{2} \times t \\
& =16 \frac{\mathrm{cm}+8 \mathrm{~cm} \times 4}{2} \\
& =48 \mathrm{~cm}^{2}\end{aligned}$ & $\begin{aligned} L & =a \times t \\
& =8 \mathrm{Bm} \times \mathrm{Gcm} \\
& =48 \mathrm{~cm}\end{aligned}$ & $\begin{array}{l}2=\frac{s+5}{2} \times t \\
\frac{10 \mathrm{um}+A \mathrm{um}}{2} \times 4 \mathrm{~cm} \\
=48 \mathrm{~cm}^{2}\end{array}$ & $\begin{aligned} L= & =\frac{d_{1} \times d_{1}}{10^{2} \mathrm{~m} y \mathrm{gcm}} \\
& =48 \mathrm{~cm}^{2}\end{aligned}$ & $\begin{aligned} L & =\frac{d_{1} \times d_{2}}{2} \\
& =\frac{12 \mathrm{~cm} \times 8 \mathrm{~cm}}{2} \\
& =\frac{96}{2} \cdot 48 \mathrm{~cm}^{2}\end{aligned}$ \\
\hline
\end{tabular}

Gambar 10 Jawaban tertulis soal nomor 1 subjek LNM

Kefasihan yang ditunjukkan dengan baik oleh subjek LNM tidak diikuti oleh dua indikator lainnya yaitu fleksibilitas dan kebaruan. Subjek LNM mengalami kesulitan dalam memberikan alternatif jawaban untuk menemukan luas trapesium yang dia buat seperti pada Gambar 11. Subjek kesulitan ketika hendak membagi trapesium menjadi bangun lain untuk dicari luasnya, yang terjadi subjek malah membagi trapesium tersebut menjadi dua trapesium lain yang malah akan mempersulit subjek LNM dalam menjawab. Berdasarkan hal tersebut menunjukkan bahwa subjek LNM belum memiliki fleksibilitas dalam dirinya.

Sama halnya dengan indikator fleksibilitas, subjek LNM juga belum mampu memberikan sesuatu yang baru dan berbeda, seperti yang terlihat pada Gambar 12, subjek LNM membuat soal yang hampir sama dengan soal sebelumnya dan belum mampu membuat tipe soal yang berbeda. Subjek masih membuat soal yang pada umumnya. Kesamaan tipe soal yang dibuat oleh subjek LNM menunjukkan bahwa subjek belum mampu memenuhi indikator kebaruan dalam dirinya.

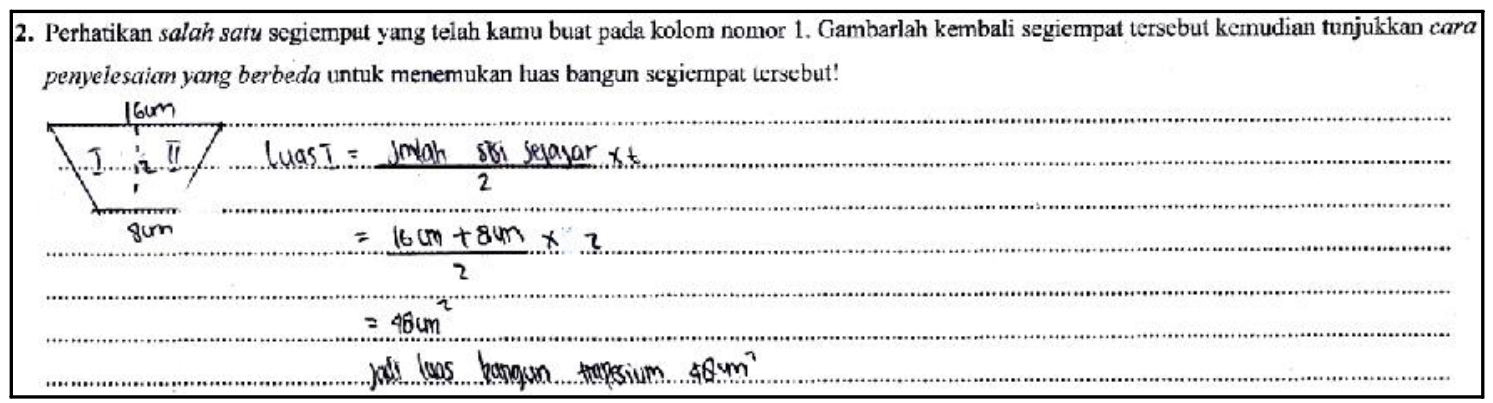

Gambar 11 Jawaban tertulis soal nomor 2 subjek LNM

a. Buatlah soal yang berbeda tentang segiempat!

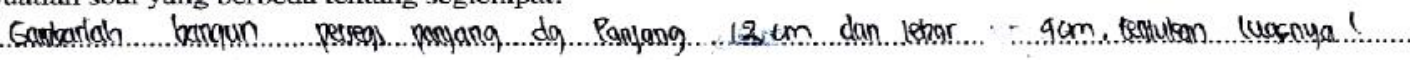

Gambar 12 Jawaban tertulis soal nomor 3 subjek LNM 
Subjek RNW memiliki Tingkat Kemampuan Berpikir Kreatif 0

Subjek yang termasuk dalam TKBK 0 (tidak kreatif), menunjukkan bahwa subjek belum mampu memunculkan ketiga indikator dari kemampuan berpikir kreatif. Motivasi subjek dalam menjawab secara lisan juga terlihat lemah. Subjek RNW kesulitan saat harus memberikan jawaban yang bermacam-macam atau bervariasi terlihat pada Gambar 13. Subjek RNW mampu memberikan 4 segiempat beserta ukurannya, hanya saja ukuran pada beberapa trapesium yang dia buat, seperti yang terlihat pada Gambar 14. Subjek RNW hanya menyalin jawaban pada soal sebelumnya dan tidak membuat penyelesaian atau cara lain untuk menemukan luas bangun yang dia gambar. Hal tersebut menunjukkan bahwa subjek RNW belum fleksibel dalam menjawab terlihat dari bagaiman subjek tidak mampu memberikan cara lain dalam mencari luas bangun yang dia buat.

Salah satu indikator yang penting pada kemampuan berpikir kreatif yaitu kebaruan juga tidak mampu diperlihatkan

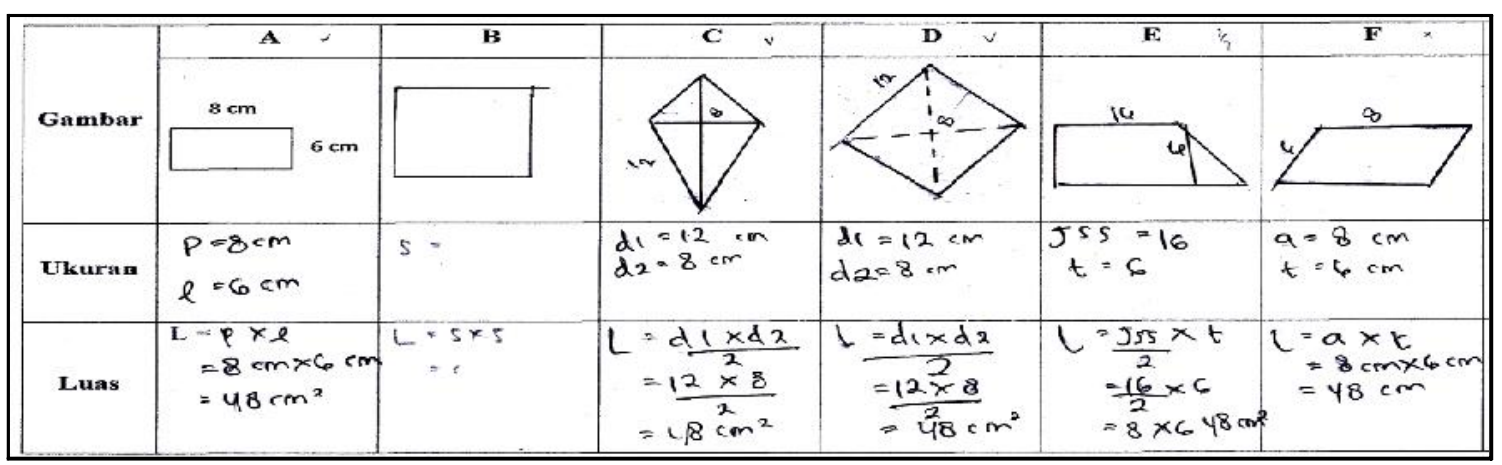

Gambar 13 Jawaban tertulis soal nomor 1 subjek RNW

segiempat kurang tepat penulisannya, sebagai contoh ukuran tinggi jajargenjang dituliskan pada sisi miringnya. Beberapa jawaban belum tepat yang diberikan subjek RNW menunjukkan bahwa subjek belum memiliki kefasihan, subjek RNW terkesan menjawab dengan apa adanya atau seingat dia saja.

Subjek RNW juga kesulitan memberikan cara lain dalam menemukan luas oleh subjek RNW, pada Gambar 14. menunjukkan bahwa subjek RNW belum mampu membuat sesuatu yang baru dan berbeda dari tingkat lainnya.

Terlihat pada Gambar 15, subjek RNW mampu membuat soal dan menyelesaikannya walaupun masih setengah jalan, namun soal yang dibuat oleh subjek masih terbilang sangat umum yaitu hanya mencari luas dari suatu bangun persegi panjang

2. Perhatikan salah saiu segicmpat yang telah kamu buat pada kolom nomor 1. Gambarlah kembali segiempat tersebut kemudian tunjukkan cara
penyelesaian yang berbeda untuk menemukan luas bangun segiempat tersebut:

Gambar 14 Jawaban tertulis soal nomor 2 subjek RNW 


\section{a. Buatlah soal yang berbeda tentang segiempat!} Hetunglah luor bargun persegi panjang berikut !

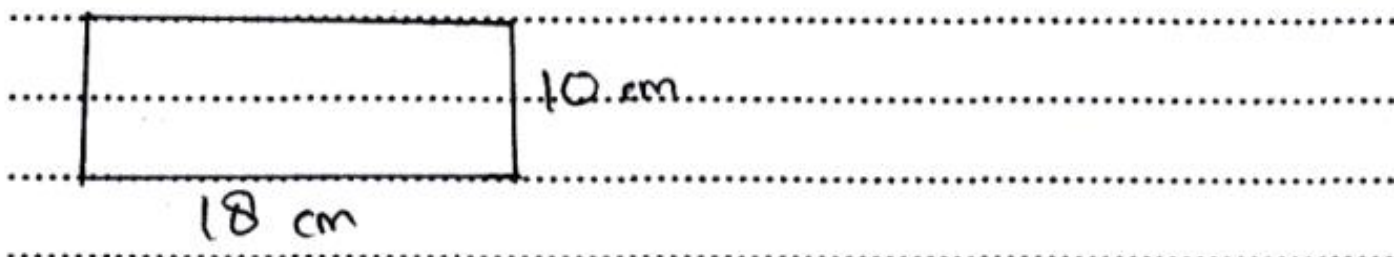

Gambar 15 Jawaban tertulis soal nomor 3 subjek RNW

sehingga belum menunjukkan adanya kebaruan dari soal tersebut.

\section{PENUTUP}

Berdasarkan analisis dan pembahasan yang telah dilakukan dapat disimpulkan bahwa kelima subjek yang mewakili tiap tingkat kemampuan berpikir kreatif memiliki karakter yang berbeda-beda dalam memperlihatkan indikator kemampuan berpikir kreatif. Subjek yang mewakili tingkat kemampuan berpikir kreatif 4 mampu memunculkan semua indikator kemampuan berpikir kreatif secara baik, yaitu kefasihan, fleksibilitas dan kebaruan dalam menyelesaikan soal. Subjek yang mewakili tingkat kemampuan berpikir kreatif 3 mampu memunculkan dua dari tiga indikator kemampuan berpikir kreatif, dalam hal ini yang dimunculkan oleh subjek adalah kefasihan dan fleksiblitas yang baik ketika menyelesaikan soal. Subjek yang mewakili tingkat kemampuan berpikir kreatif 2 mampu memunculkan satu indikator kemampuan berpikir kreatif yaitu fleksibilitas, subjek mampu memberikan lebih dari satu alternatif jawaban secara baik. Subjek yang mewakili tingkat kemampuan berpikir kreatif 1 mampu memunculkan indikator kemampuan berpikir kreatif yaitu kefasihan, subjek dengan Fasih dapat menyelesaikan soal dengan bervariasi jawaban.Subjek yang mewakili tingkat kemampuan berpikir kreatif 0 tidak mampu memunculkan ketiga indikator kemampuan berpikir kreatif dengan baik; kefasihan, fleksibilitas dan kebaruan belum mampu terlihat dari jawaban yang diberikan oleh subjek.

Melihat dari deskripsi yang ditunjukkan diatas membuat perlunya dibuat solusi yang baik pada perlakuan yang diberikan guru saat pembelajaran agar siswa mampu memberikan tingkat kemampuan berpikir kreatif terbaiknya. Oleh karena itu, guru perlu mempersiapkan diri untuk memberikan perlakuan yang sesuai terhadap siswa dengan memperhatikan tingkat kemampuan berpikir kreatif siswa, sehingga siswa lebih mampu mengembangkan berpikir kreatifnya.

\section{DAFTAR PUSTAKA}

Depdiknas. 2006. Peraturan Menteri Pendidikan Nasional No 22. Jakarta: Dirjen....?

Fardah, Dini Kinanti. 2012. Analisis Proses dan Kemampuan Berpikir Kreatif Siswa dalam Matematika Melalui Tugas Open-Ended. Jurnal Kreano, ISSN: 2086-2334. Semarang: Jurusan Matematika FMIPA UNNES Vol 3 No 2 Desember 2012.

Foong, Pui Yee. 2002. Using Short Open Ended Mathematics Question to Promote Thinking and Understanding. 
Tersedia: http://math.unipa.it/ grim/ SiFoong.pdf

Mahmudi, Ali. 2010. Mengukur Kemampuan Berpikir Kreatif Matematis. Makalah pada Konferensi Nasional Matematika XV. FMIPA Universitas Negeri Yogyakarta.

Munandar, Utami. 2012. Pengembangan Kreativitas Anak Berbakat. Jakarta: Rineka Cipta.

Putri, V. S. P. 2013. Identifikasi Tingkat Kemampuan Berpikir Kreatif (TKBK) Siswa dalam Menyelesaikan Soal Open-Ended pada Materi Segi Empat di Kelas VIII SMP. Jurnal (Online). Tersedia: http://ejournal. unesa.ac.id/index.php/mathedunesa/ article/view/2708/baca-artikel

Silver, E. A. 1997. Fostering Creativity through Instruction Rich in Mathematical Problem Solving and Problem Posing. Zentralblatt fur Didaktik der Mathematik(ZDM) - The International Journal on Mathematic Education (Online). Tersedia: http:// e mis.de/journals / Z D M / zdm973a3.pdf
Siswono, Tatag Y E. 2006. Implementasi Teori Tentang Tingkat Berpikir Kreatif dalam Matematika. Jurnal (Online). Tersedia: https://tatagyes. files.wordpress.com/2007/10/ tatag_jurnal_unej.pdf

Siswono, Tatag Y E.. 2007. Desain Tugas untuk Mengidentifikasi Kemampuan Berpikir Kreatif Siswa dalam Matematika. Jurnal (Online). Tersedia: https://tatagyes.files. wordpress.com/ 2007/10/tatag_jurnal_unej.pdf

Sugiyono. 2012. Metode Penelitian Pendidikan Pendekatan Kuantitatif, Kualitatif, dan $R \& D$. Bandung: Alfabeta.

Sulistiyana, Tri. 2012. Pengaruh Pembelajaran Matematika Realistik Terhadap Kreativitas Berdasarkan Gender Siswa Pada Pokok Bahasan Mengidentifikasi Sifat-Sifat Bangun Datar Kelas V SD Semester 2 Gugus Ki Hajar Dewantara Kabupaten Grobogan Tahun Pelajaran 2011/2012. Skripsi. Fakultas Keguruan dan Ilmu Pendidikan. Salatiga: Universitas Kristen Satya Wacana. 